\title{
PENGARUH PEMBERIAN INFUSA DAUN KERSEN (Muntingia calabura L.) TERHADAP KADAR GLUKOSA DARAH MENCIT PUTIH (Mus musculus) YANG DIBERI BEBAN GLUKOSA
}

\author{
Mira Febrina ${ }^{1 *}$, Ses Filda Sari ${ }^{1}$

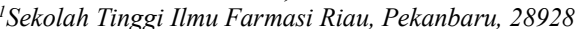 \\ I*e-mail :mirafebrina@stifar-riau.ac.id
}

\begin{abstract}
ABSTRAK
Telah dilakukan penelitian tentang pengaruh infusa daun kersen (Muntingia calabura L.) terhadap kadar glukosa darah mencit putih (Mus musculus) jantan yang diberi beban glukosa. Penelitian ini bertujuan untuk melihat pengaruh infusa daun kersen (Muntingia calabura L.) terhadap kadar glukosa darah mencit putih (Mus musculus) jantan yang diberi beban glukosa sebanyak $0,65 \mathrm{ml} / 20 \mathrm{gBB}$. Penelitian ini menggunakan metode Tes Toleransi Glukosa Oral (TTGO). Hewan percobaan dibagi menjadi 6 kelompok. Kelompok kontrol negatif hanya diberi aquadest, kelompok positif diberi metformin dengan dosis $1,3 \mathrm{mg} / 20 \mathrm{gBB}$, kelompok pembanding diberi larutan glukosa $0,65 \mathrm{ml} / 20 \mathrm{gBB}$, kelompok perlakuan diberi sediaan infusa daun kersen (Muntingia calabura L.) dengan konsentrasi 5, 10 dan 20\%. Setelah masing-masing hewan uji diberi perlakuan 30 menit kemudian diberi glukosa $0,65 \mathrm{ml} / 20 \mathrm{gBB}$ secara peroral. Kemudian dilakukan pengukuran kadar glukosa darah mencit pada menit 30-180. Berdasarkan hasil pengujian infusa daun kersen (Muntingia calabura L.) menunjukkan bahwa konsentrasi 5, 10 dan 20\% memiliki penurunan kadar glukosa darah mencit putih (Mus musculus) dengan kontrol normal. Akan tetapi dari hasil uji ANOVA dua arah dilanjutkan dengan uji Post Hoc Tukey menunjukkan bahwa konsentrasi $20 \%$ berbeda signifikan dengan konsentrasi 5 dan $10 \%$. Dan hasil yang diperoleh juga menunjukkan bahwa lama pemberian dapat mempengaruhi penurunan kadar glukosa darah mencit $(\mathrm{p}<0,05)$.
\end{abstract}

Kata kunci: Infusa daun kersen, metformin, TTGO

\section{ABSTRACT}

A study on the effect of cherry leaf infusion (Muntingia calabura L.) on glucose levels of male white mice (Mus musculus) given glucose load. This study aims to see the effect of cherry leaf infusion (Muntingia calabura L.) to blood glucose levels of male white mice (Mus musculus) given glucose load as much as $0.65 \mathrm{ml} / 20 \mathrm{gBB}$. This research used Oral Glucose Tolerance Test (TTGO) method. Animal experiments were divided into 6 groups. The negative control group was given only aquadest, the positive group was given metformin with the dosage of $1.3 \mathrm{mg} / 20 \mathrm{gBB}$, the comparison group was given $0.65 \mathrm{ml} / 20 \mathrm{gBB}$ glucose solution, the treatment group was given cesen leaves infusion (Muntingia calabura $\mathrm{L}$.) with concentration 5 , 10 and $20 \%$. After each test animal was given 30 minutes treatment then given glucose $0.65 \mathrm{ml} / 20 \mathrm{gBB}$ orally. Then measured blood glucose levels of mice at minute 30-180. Based on the results of testing the infusion of kersen leaf (Muntingia calabura L.) showed that the concentrations of 5, 10 and $20 \%$ had decreased levels of white mice blood glucose (Mus musculus) with normal control. However, the results of the two-way ANOVA assay continued with the Post Hoc Tukey test showed that the concentration of $20 \%$ differed significantly with the concentrations of 5 and $10 \%$. And the results obtained also indicate that the duration of administration may affect the decrease in blood glucose levels of mice $(p<0.05)$.

Keywords: Cherry leaf infusion, metformin, TTGO

\section{PENDAHULUAN}

Seiring dengan perkembangan ilmu pengetahuan dan teknologi serta perubahan gaya hidup dan sosial ekonomi akibat dari modernisasi terutama banyak dijumpai masyarakat kota-kota besar di Indonesia menjadi penyebab meningkatnya suatu penyakit degeneratif yang menjadi penyebab utama kematian di Indonesia. Salah satu yang harus diwaspadai adalah diabetes melitus (DM) (Soegondo et al, 2009).

Angka kesakitan dan kematian yang ditimbulkan dari penyakit ini sangat tinggi. Secara global WHO memperkirakan diabetes termasuk dalam PTM (penyakit tidak menular) ini telah menyebabkan sekitar $60 \%$ kematian dan $43 \%$ kesakitan di seluruh dunia. Diabetes dapat menimbulkan komplikasi pada mata, ginjal, pembuluh darah dan saraf yang akan berakibat kematian (Anonim, 2013).

Jumlah penduduk Indonesia saat ini diperkirakan mencapai 240 juta. Menurut data RISKESDAS 2007, prevalensi nasional DM di Indonesia untuk usia di atas 15 tahun sebesar 5,7\% (Anonim, 2013). Berdasarkan data IDF 2014, saat ini diperkirakan 9,1 juta orang penduduk didiagnosis sebagai penyandang DM. Dengan angka tersebut Indonesia menempati peringkat ke-5 di dunia, atau naik dua peringkat di dunia dengan 7,6 juta orang penyandang DM (Anonim, 2013)

Data-data di atas menunjukkan bahwa jumlah penyandang DM di Indonesia sangat besar. Dengan kemungkinan terjadi peningkatan jumlah penyandang DM di masa mendatang akan menjadi beban yang sangat berat untuk dapat ditangani sendiri oleh dokter atau bahkan oleh semua tenaga kesehatan yang ada. Penyakit DM sangat berpengaruh terhadap kualitas sumber daya manusia dan berdampak pada peningkatan biaya kesehatan yang cukup besar. Oleh karenanya semua pihak, baik masyarakat maupun pemerintah, seharusnya ikut serta secara aktif dalam upaya penanggulangan DM, khususnya dalam upaya pencegahan (Anonim, 2015).

Penggunaan obat hipoglikemia oral merupakan pilihan utama dalam menangani penyakit diabetes melitus. Penggunaan obat hipoglikemia oral ini biasanya berlangsung lama dengan efek samping yang ditimbulkan cukup besar, sehingga biaya yang dikeluarkan oleh penderita secara keseluruhan cukup besar. Maka diperlukan suatu alternatif pengobatan tersebut adalah penggunaan obat tradisional dari 
tanaman alam. Obat tradisional sejak dahulu telah digunakan oleh masyarakat secara luas dalam upaya meningkatkan pelayanan kesehatan untuk mengobati berbagai penyakit maupun digunakan sebagai bahan makanan atau kebutuhan lainnya. Agar peranan obat tradisional khususnya tumbuhan berkhasiat obat dalam pelayanan kesehatan dapat lebih ditingkatkan, maka perlu dilakukan upaya berupa pengenalan, pengujian, penelitian dan pengembangan obat tradisional yang ternyata berhasil dan berdayaguna serta dapat diterima oleh masyarakat (Wikayakusuma, 1995).

Salah satu tumbuhan yang dijadikan sebagai obat adalah tumbuhan kersen. Kersen merupakan salah satu tumbuhan yang memiliki kegunaan dari kulit batang, buah hingga daun. Jika mengacu pada sumber pustaka yang ada, sebenarnya tumbuhan kersen dapat dimanfaatkan dengan baik karena keberadaannya yang melimpah dan dapat tumbuh dimana saja. Tumbuhan kersen tidak mengenal musim panen dan mudah tumbuh, mulai dari lahan yang tandus, di antara reruntuhan bangunan bahkan menempel pada dinding tembok. Daun kersen digunakan sebagai obat tradisional pada masyarakat Kuansing sebagai antidiabetes yaitu dengan cara merebus daun kersen dan diminum. Kepercayaan masyarakat Kuansing ini adalah dengan penggunaan daun kersen pada hitungan bilangan ganjil seperti pemakaian untuk 3 helai, 7 helai, 14 helai dan 21 helai yang dilarutkan di dalam satu gelas setara dengan $250 \mathrm{ml}$ air.

Berdasarkan penelitian yang telah dilakukan, ekstrak etanol daun kersen (Muntingia calabura L) mampu menghambat peningkatan kadar gula darah pada tikus putih jantan galur wistar. Hasil penelitian tersebut menunjukkan bahwa ekstrak etanol daun kersen (Muntingia calabura L) pada dosis $0,25 \mathrm{~g} / \mathrm{kg} \mathrm{BB}$ dan dosis $0,3125 \mathrm{~g} / \mathrm{kg} \mathrm{BB}$ dan sebanding dengan metformin (dosis $63 \mathrm{mg} / \mathrm{kg} \mathrm{BB}$ ) (Apriyanti, 2016).

Penelitian sebelumnya uji efektivitas anti diabetes ekstrak daun kersen (Muntingia calabura L.) terhadap penurunan kadar glukosa darah pada mencit (Mus musculus) ekstrak dibuat menjadi air perasan mempunyai efek farmakologis sebagai anti diabetes (penurunan kadar glukosa darah) dengan dosis 0,3 $\mathrm{mL} / 10 \mathrm{gr}$ berat badan (mencit) baik pada mencit jantan maupun mencit betina (Selvia et al, 2015).

Telah dilakukan juga penelitian tentang uji aktivitas antidiabetes fraksi etil asetat daun kersen (Muntingia calabura L) pada mencit diabetes yang diinduksi aloksan menunjukkan bahwa fraksi etil asetat memiliki aktivitas sebagai antidiabetes. Dari ketiga kelompok perlakuan, hanya kelompok fraksi etil asetat daun kersen dosis $240 \mathrm{mg} / \mathrm{kgBB}$ yang memberikan perbedaan signifikan dengan kontrol positif yaitu glibenklamid dengan dosis $1,3 \mathrm{mg} / \mathrm{kgBB}$ dengan nilai signifikan $\mathrm{p}<0,05$ (Utama, 2011).

Kandungan daun kersen banyak mengandung kelompok senyawa atau lignan antara lain flavonoid, tannin, triterpene, saponin dan polifenol (Huda et al,
2015). Dewi (2013) menyatakan hasil dari skrining fitokimia terhadap ekstrak etanol daun kersen dan fraksi aktif antioksidan, diketahui ektrak mengandung flavonoid, tannin dan terpenoid, sedangkan fraksi mengandung tannin dan terpenoid. Senyawa-senyawa tersebut diduga dapat menurunkan kadar glukosa darah (Apriyanti, 2016)

Oleh karena itu penelitian tentang kersen perlu dilakukan untuk mengetahui potensi dalam menurunkan kadar glukosa darah. Perbedaan mendasar pada penelitian sebelumnya adalah bentuk sediaan yang digunakan yaitu peneliti menggunakan sediaan infusa daun kersen. Hal ini karena di masyarakat pemakaian daun kersen dengan cara merebus daun kersen. Selain itu, keuntungan dari metode infusa ini adalah peralatannya mudah didapat, sederhana dan biayanya yang murah.

Berdasarkan uraian diatas, penulis tertarik untuk menguji apakah pemberian infusa daun kersen (Muntingia calabura L) dapat menurunkan kadar glukosa darah mencit putih (Mus musculus) jantan yang diberi beban glukosa.

\section{METODOLOGI}

\section{Alat dan Bahan}

Alat yang digunakan adalah Panci infusa, kain flanel, batang pengaduk, neraca analitik, neraca hewan, pipet tetes, gelas ukur, beaker gelas, tempat minum mencit, lumping, stamfer, kandang mencit, sonde oral, alat pengukur kadar gula darah/strips test (Multicheck $\left.\operatorname{Nesco}{ }^{\circledR}\right)$

Bahan yang digunakan adalah Daun kersen, aquades, metformin, larutan glukosa, norit, asam sulfat pekat $\left(\mathrm{H}_{2} \mathrm{SO}_{4} \mathrm{p}\right)$, asam asetat anhidrat $\left(\mathrm{CH}_{3} \mathrm{COOH}\right)$, amoniak $0,05 \mathrm{~N}$, asam sulfat $2 \mathrm{~N}\left(\mathrm{H}_{2} \mathrm{SO}_{4}\right)$, pereaksi mayer, logam magnesium, ferri klorida $\left(\mathrm{Fe}_{3} \mathrm{Cl}\right)$, dan asam klorida pekat ( $\mathrm{HCl} \mathrm{p})$.

\section{Pengambilan sampel daun kersen}

Daun kersen (Muntingia calabura L.) diambil dari Desa Sitorajo Kari Kecamatan Kuantan Tengah Kabupaten Kuantan Singingi Provinsi Riau. Daun buah kersen yang diambil dalam pengujian pengaruh pemberian infusa daun kersen terhadap penurunan kadar glukosa darah mencit adalah daun yang muda, segar dan tidak busuk didapatkan di Desa Sitorajo Kari Kecamatan Kuantan Tengah Kabupaten Kuantan Singingi Provinsi Riau.

\section{Identifikasi daun kersen}

Sampel tumbuhan daun kersen (Muntingia calabura L.) dalam keadaan utuh di identifikasi di Laboratorium Botani Fakultas Matematika dan Ilmu Pengetahuan Alam (FMIPA) jurusan Biologi Universitas Riau, Pekanbaru. 


\section{Skrining Fitokimia}

Metode analisis yang digunakan berdasarkan pada Harborne (1987).

a. Flavonoid

Sampel diambil kemudian dimasukkan ke dalam tabung reaksi sebanyak 5 gram. Tambahkan kloroform dan aquadest (1:1) sebanyak $5 \mathrm{ml}$. Kocok dengan baik dan biarkan beberapa saat hingga terbentuk 2 lapisan antara lapisan air dan lapisan kloroform. Ambil lapisan air untuk menguji flavonoid, fenolik dan saponin. Lapisan kloroform di ambil untuk menguji terpenoid dan steroid. Ambil lapisan air teteskan di atas plat tetes sebanyak 2 tetes kemudian ditambahkan 2 butir logam magnesium dan 2 tetes asam klorida pekat. Hasil reaksi positif akan membentuk warna jingga hingga merah.

\section{b. Alkaloid}

Uji alkaloid dilakukan dengan melarutkan dalam beberapa tetes asam sulfat $2 \mathrm{~N}$ kemudian diuji dengan 2 pereaksi alkaloid yaitu pereaksi dragendorff dan pereaksi mayer. Hasil uji positif diperoleh bila terbentuk endapan merah hingga jingga dengan pereaksi dragendorff dan endapan putih kekuningan dengan pereaksi mayer.

\section{c. Fenolik}

Sampel diambil kemudian dimasukkan kedalam tabung reaksi sebanyak 5 gram. Tambahkan kloroform dan aquadest (1:1) sebanyak $5 \mathrm{ml}$. Kocok dengan baik dan biarkan beberapa saat hingga terbentuknya 2 lapisan antara lapisan air dan kloroform. Lapisan air yang didapatkan kemudian diteteskan diatas plat tetes sebanyak 2 tetes. Kemudian tambahkan larutan ferri klorida sebanyak 2 tetes. Hasil positif akan membentuk warna hijau hingga biru gelap.

\section{d. Saponin}

Sampel diambil kemudian dimasukkan ke dalam tabung reaksi sebanyak 5 gram. Tambahkan kloroform dan aquadest (1:1) sebanyak $5 \mathrm{ml}$. Kocok dengan baik dan biarkan beberapa saat hingga terbentuknya 2 lapisan antara air dan kloroform. Lapisan air dimasukkan dalam tabung reaksi yang berbeda kemudian dikocok dengan kuat. Hasil positif membentuk busa yang tidak segera hilang pada saat didiamkan.

\section{e. Terpenoid dan steroid}

Siapkan pipet tetes yang telah dimasukkan kapan di ujung bagian dalamnya, lalu masukkan norit sampai 1/3 dari panjang pipet. Ambil lapisan kloroform kemudian dimasukkan ke dalam pipet tetes berisi norit, kemudian dibiarkan menetes diatas plat tetes dan biarkan mengering. Setelah kering, satu lubang ditambahkan asam asetat anhidrat kemudian asam sulfat pekat. Hasil positif bila terbentuk warna biru ungu menandakan adanya steroid dan terbentuk warna merah menandakan adanya terpenoid.

\section{Persiapan hewan percobaan}

Hewan percobaan yang digunakan pada penelitian ini adalah mencit putih (Mus musculus L) jantan dewasa yang sehat sebanyak 30 ekor. Umur mencit yang digunakan berkisar antara 2-3 bulan dengan berat antara 20-30 gram.

Sebelum perlakuan hewan percobaan di aklimatisasi selama 7 hari. Hewan yang digunakan untuk penelitian adalah hewan yang belum pernah diperlakukan terhadap obat dan hewan yang dinyatakan sehat dengan kriteria tidak cacat secara fisik, tidak mengalami penyimpangan berat badan $\pm 20 \%$ dan secara visual memperlihatkan perilaku yang normal (Anonim ${ }^{\mathrm{b}}$, 2014).

\section{Pembuatan infusa daun kersen}

Infusa dibuat dari daun kersen $10 \% \mathrm{~b} / \mathrm{v}$ (Anief, 1986) dengan cara sebagai berikut, daun kersen seberat 10 gram kemudian dimasukkan ke dalam panci infusa, ditambahkan aquades $100 \mathrm{ml}$. Daun kersen yang telah ditambahkan aquades dipanaskan menggunakan penangas air selama 15 menit terhitung setelah suhu dalam panci mencapai $90^{\circ} \mathrm{C}$, sambil sesekali diaduk. Diserkai selagi panas dengan menggunakan kain flanel, dijadikan $100 \mathrm{ml}$ infusa. Jika volumenya kurang dari $100 \mathrm{ml}$ dapat ditambahkan air panas yang dilewatkan pada ampas daun kersen hingga diperoleh $100 \mathrm{ml}$ volume infusa daun kersen. Infusa daun kersen yang diberikan sebagai perlakuan pada mencit yaitu dengan 3 perlakuan konsentrasi 5\%, 10\%, 20\% dengan volume pemberian $1 \%$ dari $\mathrm{BB}$.

\section{Perencanaan dosis}

Konsentrasi infusa daun kersen yang diberikan pada hewan percobaan sebagai perlakuan pada mencit yaitu dengan 3 perlakuan konsentrasi 5\%, 10\%, 20\% dengan volume pemberian $1 \%$ dari BB. Glukosa yang digunakan adalah glukosa monohidrat. Pembuatan stok glukosa yaitu dengan cara 75 gram glukosa ditimbang dan dimasukkan ke dalam labu ukur $250 \mathrm{ml}$ kemudian ditambahkan aquadest sebanyak $100 \mathrm{ml}$, selanjutnya dikocok hingga larut kemudian dicukupkan volumenya sampai $250 \mathrm{ml}$. Volume pemberian untuk setiap mencit yaitu $0,65 \mathrm{ml} / 20 \mathrm{gBB}$ (Noffritasari, 2006).

Untuk kelompok kontrol positif diberi metformin untuk mencit 20 gram jika dikonversikan $=0,0026 \mathrm{x}$ $500 \mathrm{mg}=1,3 \mathrm{mg} / 20 \mathrm{gBB}$. Setelah itu larutkan dengan aquadest dan suntikkan secara oral sebanyak 0,2 $\mathrm{ml} / 20 \mathrm{gBB}$ untuk masing-masing mencit. Sementara untuk kelompok kontrol negatif hanya diberikan aquades sebanyak $1 \mathrm{ml}$.

\section{Pengelompokkan hewan percobaan}

Pada penelitian kali ini hewan percobaan akan dibagi secara acak menjadi 6 kelompok masing-masing terdiri dari 5 ekor mencit putih jantan. Mencit dipuasakan terlebih dahulu selama 18-24 jam, tiap kelompok diberi perlakuan sebagai berikut : 
1. Kelompok pertama adalah sebagai kontrol negatif hanya diberi larutan aquadest.

2. Kelompok kedua adalah sebagai kontrol positif diberi larutan metformin $0,2 \mathrm{ml} / 20 \mathrm{gBB}$ dan 30 menit kemudian diberi larutan glukosa $0,65 \mathrm{ml} / 20$ gBB.

3. Kelompok ketiga adalah sebagai pembanding hanya diberi larutan glukosa $0,65 \mathrm{ml} / 20 \mathrm{gBB}$.

4. Kelompok keempat adalah mencit diberi perlakuan infusa daun kersen dengan konsentrasi $5 \%$ b/v dengan volume pemberian $1 \%$ dari $\mathrm{BB}$ dan 30 menit kemudian diberi larutan glukosa $0,65 \mathrm{ml} / 20$ gBB.

5. Kelompok kelima mencit diberi perlakuan infusa daun kersen dengan konsentrasi $10 \% \mathrm{~b} / \mathrm{v}$ dengan volume pemberian $1 \%$ dari $\mathrm{BB}$ dan 30 menit kemudian diberi larutan glukosa $0,65 \mathrm{ml} / 20 \mathrm{gBB}$.

6. Kelompok keenam mencit diberi perlakuan infusa daun kersen dengan konsentrasi $20 \% \mathrm{~b} / \mathrm{v}$ dengan volume pemberian $1 \%$ dari $\mathrm{BB}$ dan 30 menit kemudian diberi larutan glukosa $0,65 \mathrm{ml} / 20 \mathrm{gBB}$.

\section{Uji Toleransi Glukosa Oral (TTGO)}

Metode induksi TTGO yang digunakan dalam percobaan ini adalah metode toleransi glukosa oral dimana hewan percobaan diberi larutan glukosa sebanyak 0,65 ml/20 gBB. Mencit yang akan diberi perlakuan dipuasakan terlebih dahulu selama 18-24 jam, dengan tujuan agar sistem atau saluran pencernaannya kosong sehingga tidak akan mempengaruhi absorpsi obat.

Mencit diperiksa kadar glukosa darah awal sebelum pemberian sediaan, untuk kelompok perlakuan 4, 5 dan 6 masing-masing diberi infusa daun kersen dengan volume pemberian $1 \%$ dari berat badan hewan percobaan dengan konsentrasi masing-masing adalah $5 \%, 10 \%$ dan $20 \%$, untuk kelompok kontrol positif diberikan metformin dengan dosis 1,3 mg/20 gBB dengan volume pemberian $1 \%$ dari berat badan hewan percobaan dan kelompok kontrol negatif hanya diberikan aquades dengan volume pemberian 1\% dari berat badan hewan percobaan. Setelah 30 menit, semua mencit diperiksa kadar glukosa darah sesudah perlakuan. Selanjutnya setiap hewan percobaan dibebankan dengan larutan glukosa yang diberikan secara oral sebanyak $0,65 \mathrm{ml} / 20 \mathrm{gBB}$ setelah itu diukur kadar glukosa darah dengan menggunakan alat glukometer (Multicheck Nesco®) dan strip test pada selang waktu 30 menit selama 3 jam.

\section{Pengukuran kadar glukosa darah hewan percobaan}

Mencit yang telah diberikan sediaan per oral kemudian dibebankan larutan glukosa sebesar 0,65 $\mathrm{ml} /$ 20 gBB, dan segera diperiksa kadar glukosa darah mencit pada menit awal 30,60, 90, 120, 150 dan 180 atau dengan selang waktu 30 menit setelah menit awal $\left(\mathrm{t}_{0}\right)$ sampai menit ke-180.
Cara pengukuran kadar glukosa darah mencit menggunakan alat glukometer :

1. Sebelum pemeriksaan kadar glukosa darah, mencit dipuasakan 18-24 jam. Pemeriksaan kadar glukosa darah melalui pengambilan cuplikan darah dari vena di ekor mencit dengan cara menyayat sedikit bagian ekor mencit.

2. Tetesan darah diperiksa dengan menggunakan alat glukometer. Strip tes yang telah ditetesi darah dimasukkan ke alat pemeriksa, kemudian hasilnya dibaca pada layar dalam waktu 10 detik. Nilai yang tertera pada layar merupakan konsentrasi glukosa darah dalam mg/dl.

\section{Analisa data}

Untuk analisa data dilakukan dengan mengukur perubahan kadar glukosa dalam dara pada menit awal, $30,60,90,120,150$ dan 180 dari masing-masing kelompok setelah hewan uji mengalami diabetes dengan metoda analisa ANOVA dua arah menggunakan software SPSS 16.0 for windows.

\section{HASIL DAN PEMBAHASAN}

Penelitian ini dilaksanakan untuk melihat pengaruh pemberian infusa daun kersen (Muntingia calabura L.) terhadap kadar glukosa darah mencit putih (Mus musculus L) jantan yang diberi beban glukosa. Daun kersen (Muntingia calabura L) yang dijadikan sampel pada penelitian ini diperoleh dari Kabupaten Kuantan Singingi Kecamatan Kuantan Tengah karena secara tradisional masyarakat di Kabupaten Kuantan Singingi tersebut menggunakan daun kersen sebagai salah satu obat untuk menurunkan kadar glukosa darah. Selain hal tersebut tumbuhan ini juga mudah diperoleh serta memiliki berbagai manfaat untuk kesehatan seperti penyembuhan luka bakar (Handayani \& Sentat, 2016), asam urat (Sulistyowati, 2009).

Pada tahap awal penelitian dilakukan identifikasi tumbuhan yang dilakukan di Laboratorium Botani Fakultas Matematika dan Ilmu Pengetahuan Alam (FMIPA) jurusan Biologi Universitas Riau. Dari hasil identifikasi yang diperoleh, menyatakan tumbuhan yang digunakan adalah tumbuhan kersen dengan nama spesies (Muntingia calabura L) yang termasuk marga Muntingia. Selanjutnya daun kersen dilakukan skrining fitokimia. Tujuannya adalah untuk mengetahui golongan senyawa kimia yang terdapat dalam sampel daun kersen (Muntingia calabura L). Berdasarkan hasil skrining fitokimia yang dilakukan menunjukkan bahwa daun kersen mengandung senyawa metabolit sekunder flavonoid, fenolik dan saponin.

Dari hasil pengujian metabolit sekunder yang diperoleh, diduga kandungan flavonoid mampu menurunkan kadar glukosa darah. Flavonoid mampu meregenerasi sel beta pankreas dan mampu merangsang sekresi insulin (Dheer \& Bhatnagar, 2010). Mekanisme lain dari flavonoid yang menunjukkan efek hipoglikemia yaitu mengurangi penyerapan glukosa dan 
mengatur aktivitas sekresi enzim yang terlibat dalam metabolisme karbohidrat (Brachmachri, 2011). Efek hipoglikemia mekanisme kerjanya mirip dengan golongan sulfonilurea, yaitu meningkatkan sekresi insulin, meningkatkan reseptor insulin sehingga absorpsi glukosa di jaringan perifer meningkat, meningkatkan insulin jaringan otot, lemak dan hati serta menghambat penguraian polisakarida menjadi monosakarida (Tjay \& Rahardja, 2003).

Metabolit sekunder yang terdapat selanjutnya yaitu saponin. Saponin adalah suatu glikosida alamiah yang terikat dengan steroid atau triterpen. Doghhari (2012) menyebutkan bahwa saponin memiliki aktivitas hipoglikemik dan antikanker. Aktivitas hipoglikemik dari saponin akan menurunkan kadar lipid dalam tubuh sehingga insulin dapat berfungsi normal sebab menurut Australia National Diabetes Strategy 2016-2020 peningkatan lipid di dalam tubuh menyebabkan kerja insulin terhambat sehingga terjadi diabetes (Anonim, 2015).

Kandungan lain yang diduga dapat menurunkan kadar glukosa darah adalah fenolik yang memiliki peran meningkatkan sekresi insulin, meningkatkan ambilan glukosa ke jaringan perifer (Pinent et al, 2008), menghambat penyerapan glukosa dengan baik melalui aktivitas inhibisi kompetitif terhadap $\alpha$-glukosidase di saluran pencernaan maupun melalui penghambatan glukosa di tubulus proksimal renalis dan menghambat gluconeogenesis (Arjita el al, 2002). Berdasarkan pernyataan di atas, diperkirakan infusa daun kersen mempunyai potensi dalam menurunkan kadar glukosa darah pada mencit putih jantan, karena kandungan metabolit sekundernya yaitu flavonoid, saponin dan fenolik. Ini dibuktikan dengan pengujian TTGO pada konsentrasi 5, 10 dan 20\% infusa daun kersen ini tidak berbeda signifikan dengan kontrol positif.

Sebagai hewan percobaan dalam penelitian ini digunakan mencit putih jantan (Mus musculus). Pemilihan mencit sebagai hewan percobaan karena memiliki siklus reproduksi yang singkat, selang generasi yang pendek dan mempunyai keturunan yang relatif lebih banyak perkelahiran (Kurnianto et al, 2001). Selain itu mencit putih jantan dipilih karena mudah penanganannya, relatif murah dan mencit putih jantan tidak mengalami masa estrus yang dapat menyebabkan peningkatan kadar glukosa darah (Nugroho, 2006).

Setiap mencit ditempatkan dikandang yang berbeda. Alas kandang diberi sekam secara merata, serta setiap hari diberi pakan dan minum. Makanan yang diberikan pada mencit berupa pakan standar, sedangkan air yang diberikan berupa aquades yang diletakkan dalam botol plastic yang disumbat pipa alumunium. Sebelum dilakukan pengujian, mencit terlebih dahulu diaklimatisasi selama 1 minggu dengan tujuan agar mencit terbiasa dengan lingkungan dan tidak stress. Selama aklimatisasi mencit diberikan makan dan minum seperti biasanya. Selama aklimatisasi berat mencit ditimbang, mencit yang digunakan adalah mencit sehat yakni berat badan selama aklimatisasi tidak mengalami perubahan lebih dari $20 \%$ dan secara visual memperlihatkan perilaku yang normal (Anonim ${ }^{\mathrm{b}}$, 2014).

Setelah mencit diaklimatisasi dan memenuhi persyaratan, mencit dipuasakan selama 20-24 jam (Anonim $^{b}$, 2014) sebelum dilakukan penelitian, tujuannya adalah agar sistem atau saluran pencernaannya kosong sehingga tidak akan mempengaruhi absorpsi obat. Selanjutnya mencit dikelompokkan menjadi 6 kelompok percobaan untuk diberi perlakuan, dimana setiap kelompok terdiri dari 5 ekor mencit. Kelompok 1 sebagai kontrol negatif diberikan aquades, kelompok 2 sebagai kontrol postif diberikan larutan metformin dengan konsentrasi $65 \mathrm{mg} / 10 \mathrm{ml}$, kelompok 3 sebagai pembanding yang diberi larutan glukosa sebanyak $195 \mathrm{mg} / 20 \mathrm{gBB}$, kelompok 4, 5 dan 6 diberikan infusa daun kersen dengan konsentrasi 5, 10 dam 20\% secara oral.

Penelitian ini menggunakan metformin sebagai kontrol positif (Apriyanti, 2016). Metformin merupakan obat antidiabetes oral golongan biguanid. Metformin memiliki mekanisme kerja dengan meningkatkan sensitivitas insulin terhadap reseptornya dan tidak merangsang sekresi insulin. Selain itu, metformin juga membantu membentuk glukosa menjadi glikogen di hati. Metformin tidak merangsang sekresi insulin sehingga dalam terapi pengobatannya tidak menyebabkan hipoglikemia terhadap pasien (Gunawan dkk, 2007). Pada pembuatan larutan metformin dilarutkan dengan aquades karena menurut Farmakope Edisi IV metformin kelarutannya mudah larut dalam air yaitu 1:10 (Anonim, 1995).

Setelah mencit diberi perlakuan, pada menit ke-30 mencit akan diberi beban glukosa $195 \mathrm{mg} / 20 \mathrm{gBB}$ secara oral sebagai penginduksi (Noffritasari, 2006). Hal ini dikarenakan pada penelitian ini menggunakan metode Test Toleransi Glukosa Oral (TTGO). Tes Toleransi Glukosa Oral adalah tes yang mengukur kadar glukosa darah sebelum dan dua jam sesudah mengkonsumsi glukosa 75 gram yang dilarutkan dalam $250 \mathrm{ml}$ air (Anonim, 2010). Pada TTGO, pasien diberikan beban glukosa sebanyak $75 \mathrm{~g}$ untuk dosis manusia dewasa kemudian dikonversikan ke mencit sehingga glukosa yang digunakan pada mencit yaitu $195 \mathrm{mg} / 20 \mathrm{gBB}$. Glukosa yang disuntikkan secara oral akan meningkatkan kadar glukosa darah mencit kemudian dilihat penurunan kadar glukosa darah mencit yang akan diberikan perlakuan.

Pengujian TTGO dilakukan selama 3 jam untuk melihat kinerja pankreas dalam menghasilkan insulin untuk menormalkan kembali kadar glukosa darah (Price \& Wilson, 1997). Pada penelitian ini pengujian dilakukan selama 3 jam dengan tujuan untuk mengetahui dan melihat efek penurunan kadar glukosa darah pada selang waktu 30 menit, diharapkan absorpsi glukosa darah ke dalam jaringan teramati dengan baik. Berdasarkan penelitian Syah et al (2015) dan Tjahjadi 
(2010) menggunakan metode TTGO dapat meningkatkan kadar glukosa darah mencit.

Induksi glukosa pada mencit (Mus musculus L) dengan suntikan glukosa secara oral pada dosis $195 \mathrm{mg} / 20 \mathrm{gBB}$ telah berhasil menaikkan kadar glukosa darah mencit (Lampiran 5, Tabel 8). Pada penelitian ini kadar glukosa darah yang melebihi $200 \mathrm{mg} / \mathrm{dl}$ dianggap telah diabetes karena menurut Perkeni (2015) pemeriksaan TTGO jika telah melebihi kadar glukosa $200 \mathrm{mg} / \mathrm{dl}$ dinyatakan diabetes. Pada penelitian ini kadar glukosa darah mencit diukur menggunakan alat Multicheck Nesco ${ }^{\circledR}$. Alat ini dapat mengukur kadar glukosa darah dengan rentang 20-600 mg/dl, serta hanya membutuhkan sedikit darah saja. Pemilihan penggunaan alat ini karena kerjanya yang mudah, praktis dan dapat membaca kadar glukosa darah dalam 10 detik setelah diteteskan darah pada strip test. Prinsip kerja dari alat ini berdasarkan reaksi enzimatis yaitu glukosa dengan adanya oksigen dioksidasi oleh enzim glukosa oksidase yang terdapat dalam strip test membentuk asam glukoronat dan hidrogen peroksida. Selanjutnya hidrogen peroksida yang terbentuk akan mengoksidasi orto toluidin yang dikatalis oleh enzim peroksidase menghasilkan warna biru. Intensitas warna biru orto toluidin yang teroksidasi diukur oleh alat yang setara dengan kadar gula darah (Sherwood, 2007).

Analisa data pada penelitian menggunakan ANOVA dua arah karena pada pengujian ini melihat pengaruh perlakuan dan waktu terhadap kadar glukosa darah pada mencit. Pada pengujian ini menggunakan nilai signifikan $\alpha=0,05$, apabila nilai $p>0,05$ maka tidak dilanjutkan uji tukey dan apabila nilai $\mathrm{p}<0,05$ maka dilanjutkan uji tukey untuk melihat kelompok mana yang berbeda signifikan. Analisa data penurunan kadar glukosa darah pemberian infusa daun kersen (Muntingia calabura L) dengan konsentrasi 5, 10 dan 20\% dapat memberi pengaruh terhadap penurunan kadar glukosa darah mencit yang diberi beban glukosa $195 \mathrm{mg} / 20 \mathrm{gBB}$. Hasil data statistik penelitian menunjukkan bahwa adanya perbedaan signifikan perubahan kadar glukosa darah yang ditimbulkan oleh kelompok mencit yang diberikan infusa daun kersen dengan 5, 10, 20\% terhadap kelompok mencit yang diberikan air minum biasa sebagai kelompok kontrol negatif.

Tabel 1. Hasil Uji Homogenitas Terhadap Perlakuan Berdasarkan Analisis Statistik

\begin{tabular}{|l|c|}
\hline Kelompok Perlakuan & Gula Darah Perlakuan \\
\hline $\begin{array}{l}\text { Kontrol Negatif (Hanya } \\
\text { diberikan aquadest) }\end{array}$ & $73,91^{\mathrm{a}}$ \\
\hline $\begin{array}{l}\text { Kontrol Positif } \\
\text { (Glukosa + Metforfim) }\end{array}$ & $155,20^{\mathrm{b}}$ \\
\hline Pembanding (Glukosa) & $180,34^{\mathrm{d}}$ \\
\hline Konsentrasi 5\% & $165,03^{\mathrm{c}}$ \\
\hline Konsentrasi $10 \%$ & $167,66^{\mathrm{c}}$ \\
\hline Konsentrasi $20 \%$ & $136,14^{\mathrm{b}}$ \\
\hline
\end{tabular}

Keterangan : Abjad yang berbeda menunjukkan adanya perbedaan signifikan $(\mathrm{P}<0,05)$

Seterusnya hasil data statistik ANOVA dua arah yang dilanjutkan dengan Post Hoc Tukey juga menunjukkan konsentrasi $20 \%$ tidak berbeda signifikan dengan kontrol positif terhadap penurunan kadar glukosa darah mencit putih jantan. Hal ini menunjukkan bahwa konsentrasi $20 \%$ memiliki efek sebanding dengan kontrol positif yang diberi antidiabetik oral yaitu metformin terhadap penurunan kadar glukosa darah . Konsentrasi $20 \%$ dan kontrol positif berbeda signifikan dengan kontrol negatif, konsentrasi 5\%, $10 \%$ dan pembanding. Hal ini dapat membuktikan bahwa dosis efektif infusa daun kersen dalam penurunan kadar glukosa darah adalah pada konsentrasi 20\%. Hal ini juga membuktikan bahwa dengan adanya peningkatan dosis akan berpengaruh pula pada peningkatan efek antidiabetes yang dihasilkan.

\section{SIMPULAN}

Dari hasil pengujian Tes Toleransi Glukosa Oral (TTGO) pada pemberian infusa daun kersen (Muntingia calabura L.) pada konsentrasi $20 \%$ memiliki efek menurunkan kadar glukosa darah mencit putih (Mus musculus) yang diberi beban glukosa secara oral.

\section{DAFTAR PUSTAKA}

Anief, M., 1986. Ilmu Farmasi. Ghalia Indonesia. Jakarta.

Anonim, 1995. Farmakope Indonesia Departemen Kesehatan Republik Indonesia, ed., Jakarta.

Anonim, 2010. Diagnosis and Classifications of Diabetes Mellitus. Journal of American Diabetes Assosiation, Available at http://doi.org/10.2337/dc10-S062, diakses tanggal 15 Maret 2017.

Anonim, 2013. The Diagnosis Treatment and Prevention of Diabetes Mellitus. World Health Organization. Available at: http://www.who.int, diakses tanggal 23 Oktober 2016.

Anonim ${ }^{\text {b }}$, 2014. Pedoman Uji Toksisitas Non Klinik Secara In Vivo. Badan Pengawasan Obat dan Makanan, diakses tanggal 21 Februari 2017.

Anonim, 2015. Australia National Diabetes Strategy. www.health.gov.au, diakses tanggal 18 juli 2017.

Apriyanti, E., 2016. Efek Ekstrak Etanol Daun Kersen (Muntingia calabura L) Terhadap Penghambatan Peningkatan Kadar Gula Darah Pada Tikus Putih Jantan Galur Wistar. Skripsi Sarjana Sekolah Tinggi Ilmu Kesehatan Ngudi Waluyo, diakses tanggal 27 Oktober 2016.

Arjita, I.P.D., Widodo, M.A. \& Widjajanto, E., 2002. Pengaruh Kadar Glukosa Tinggi Terhadap Sintesis Nitric Oxide dari Human Umbilical Vein Endothelial Cells (HUVEs) Culture dengan Teknik Bioessay. Biosains, Volume 1 Nomor 3.

Brahmachri, G., 2011. Bio-Flavonoids With Promising Antidiabetic Potentials : A Critical Survey. Research Signpost, Volume 2 Nomor 7, pp.187-212.

Dewi, E.T., 2013. Fraksinasi dan Identifikasi Senyawa Antioksidan pada Ekstrak Etanol Daun Kersen (Muntingia calabura L.) Secara Kolom Kromatografi. Skripsi Fakultas Farmasi Universitas Katolik Widya Mandala Surabaya.

Dheer, R. \& Bhatnagar, P., 2010. A Study of the Antidiabetic Activity of Barleria prionitis Linn. Indian Journal of Pharmacology, 42(5): 70-73. 
Doughari, J.H., 2012. Phytochemical: Extraction Methods, Basic Structure and Mode of Action as Potential Chemotherapeutic Agents, Phytocemical- A Global Prescriptive of Their Role in Nutrition and Health. www.intechopen.com, diakses tanggal 25 juli 2017.

Gunawan, S.G., Setiabudy, R. \& Nafrialdi, E., 2007. Farmakologi dan Terapi. Departemen Farmakologi dan Terapeutik Fakultas Kedokteran Universitas Indonesia. Jakarta,

Handayani, F. \& Sentat, T., 2016. Uji Aktivitas Ekstrak Etanol Daun Kersen (Muntingia calabura L) Terhadap Penyembuhan Luka Bakar Pada Kulit Mencit Putih (Muntingia calabura L) Jantan. Jurnal Ilmiah Ibnu Sina, Volume 1 Nomor 2, pp 131142.

Harborne, J.B., 1987. Metode Fitokimia: Penuntun Cara Modern Menganalisis Tumbuhan. Intitut Teknonologi Bandung. Bandung.

Huda, S., Sahputra, A. \& Wahyuni, R., 2015. Pemanfaatan Daun Kersen (Muntingia calabura L) Sebagai Permen Jelly Terhadap Daya Terima Konsumen. Skripsi Sarjana Fakultas Pertanian Universitas Yudharta Pasuruan, diakses tanggal 27 November 2016

Kurnianto, E., Sutopo \& Setiatin, E.T., 2001. Perkembangbiakan dan Penampilan Mencit Sebagai Hewan Percobaan. Laporan Penelitian Fakultas Peternakan Universitas Diponegoro. Semarang.

Noffritasari, B., 2006. Pengaruh Pemberian Daun Kacapiring (Gardenia augusta Merr) terhadap Kadar Glukosa Darah mencit putih jantan yang diberi Beban Glukosa. Karya Tulis Ilmiah. Universitas Diponegoro. Semarang.

Nugroho, A.E., 2006. Review Hewan Percobaan Diabetes Melitus : Patologi dan Mekanisme Aksi Diabetogenik. Biodiversitas, Volume 2 Nomor 1, pp 57-60

Perkeni, 2015. Konsesus Pengelolan dan Pencegahan Diabetes Melitus Tipe 2 di Indonesia. In PB Perkeni. Jakarta.
Pinent, M. et al., 2008. Bioactivity of Flavonoid on Insulin Secreting Cells. Compr Rev Food Sci Food Safety, Volume 7 Nomor 1 pp.299-308.

Price, S.A. \& Wilson, L.M., 1997. Patofisiologi: Konsep Klinis Proses-Proses Penyakit Edisi IV. EGC. Jakarta.

Selvia, A. et al., 2015. Uji Efektivitas Ektrak Daun Kersen (Muntingia calabura L) terhadap Penurunan Kadar Glukosa Darah pada Mencit (Mus musculus). FMIPA Universitas Hasanudin.

Sherwood, L. 2015. Organ Endokrin Perifer, Fisiologi Manusia dari Sel ke Sistem, Terjemahan: Bramh U. Buku Kedokteran EGC. Jakarta

Soegondo, S., Soewondo, P. \& Subekti, I., 2009. Penatalaksanaan Diabetes Mellitus Terpadu Edisi kedua. Balai Penerbit FKUI. Jakarta.

Sulistyowati, V.Y., 2009. Efek Pemberian Ekstrak Daun Talok (Muntingia calabura L) Terhadap Kadar Asam Urat Serum Tikus Putih (Rattus norvegicus L) Galur Wistar Hiperurikemia. Skripsi Universitas Sebelas Maret.

Syah, M.I., Suwendar \& Mulqie, L., 2015. Uji Aktivitas Antidiabetes Ekstrak Etanol Daun Mangga Arumanis "Mangifera Indica L" pada Mencit Swiss Webster Jantan dengan Metoda Tes Toleransi Glukosa Oral. Prosiding Penelitian Sivitas Akademika Unisba, Volume 1 Nomor 9, pp 1-5.

Tjay, T.H. \& Rahardja, K., 2002. Obat-obat Penting Khasiat, Penggunaan dan Efek Sampingnya. PT. Elex Media. Jakarta.

Utama, R.P., 2011. Uji Aktivitas Anti Diabetes Fraksi Etil Asetat Daun Kersen (Muntingia calabura L) Pada Mencit Diabetes Akibat Induksi Aloksan. Skripsi Sarjana Fakultas Farmasi, Universitas Jember.

Wikayakusuma, H., 1995. Tanaman Berkhasiat Obat di Indonesia Jilid II. Pustaka Kartini. Jakarta 